\begin{tabular}{|c|c|c|}
\hline & $\begin{array}{c}\text { International Journal of Current Research in } \\
\text { Biosciences and Plant Biology }\end{array}$ \\
\hline EXCELLENT \\
PUBLISHERS
\end{tabular}

Review Article

doi: http://dx.doi.org/10.20546/ijcrbp.2017.401.013

\title{
Bamboo - A Miracle Plant
}

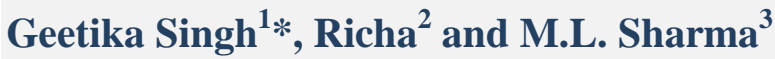 \\ ${ }^{I}$ Assistant Professor, MCM DAV College for Women, Sector-36 A, Chandigarh - 160 036, India \\ ${ }^{2}$ Professor, Department of Botany, Panjab University, Sector 14, Chandigarh - 160 014, India \\ ${ }^{3}$ Professor Emeritus, Department of Botany, Panjab University, Sector 14, Chandigarh - 160 014, India
}

*Corresponding author.

\begin{abstract}
This review paper is based on the versatile and numerous uses of bamboo grass plant. They are some of the fastest growing plants. Bamboos as construction material are associated with south and east Asia. Bamboos long life make it symbol of uprightness in china and symbol of friendship in India. It is used by rural people for food, housing and other domestic purposes. They are used in Chinese traditional medicine for treating various ailments and are rich source of nutrients. They can be further exploited for various other medicinal uses.
\end{abstract}

\section{Article Info}

Accepted: 01 January 2017

Available Online: 06 January 2017

Keywords

Bamboo

Bambusa arundinacea

Phyllostachys species

\section{Introduction}

The Bamboos are arborescent grasses belonging to family Poaceae, subfamily Bambusoideae and tribe Bambuseae. Bamboos include some of the fastest growing plants in the world due to its unique rhizome dependent system. There are 110 genera and 1500 species of bamboos distributed in tropical and temperate zones of different parts of the globe (Sharma, 1987). Bamboos occupy habitats from sea level to high mountains. However, increasing demands from rural population, urban centres and international trade are leading to declining stock and hence increasing concern about its conservation. Also due to enhanced demands from the industry, the bamboo stock of country is fast decreasing due to overexploitation. Bamboos are indeed one of nature's miracles and their strength and structure enables them to be put to diverse uses. In Asia, bamboos are the essence of life for many communities, and it no exaggeration to speak of 'Bamboo Civilization' in the region. Bamboo is a long stick like non-wood forest product and sometimes used as wood substitute.

Moreover, as it is found any regions of the world and plays an important economic role. Even though it is used for housing, crafts, pulp, paper, panels, boards, veneer, flooring, roofing, fabrics and vegetable (the bamboo shoot). Products of bamboos are using everywhere and bamboo industries are now thriving in Asia and are quickly expanding across the continents to Africa and America. Lack of reliable, comprehensive data on bamboo resources and utilization hampers their sustainable development and limits their potential to contribute to poverty reduction (FAO, 2007). 


\section{Uses of bamboo as construction material}

Timber is largely harvested from bamboos both in cultivated and wild form as therefore also known as 'Timber bamboos'. Bamboo as construction material is associated with cultures of South and East Asia. Bamboo intended for use in construction should be treated to resist insects and rot. The most common solution for this purpose is a mixture of borax and boric acid (Nijhuis, 2009).

Another process involves boiling cut bamboo to remove the starches that attract insects. In Japanese architecture, bamboo is used primarily as a supplemental and/or decorative element in buildings such as fencing, fountains, grates and gutters, largely due to the ready abundance of quality timber (Bess and Wein, 1987).

\section{Uses of bamboo as food}

In Northern China and Japan, the monopodial bamboo species such as Phyllostachys edulis, P. mitis and $P$. pubescens are most common and prepared delicious bamboo shoot (McClure, 1996). However, plantation of bamboo should be encouraged and promoted due to their high value, productivity, uniformity of crop, choice of species linked to peoples' and industrial need. It is estimated that bamboo plants constitutes about $13 \%$ of the total forest area of the India.

Bamboo is wealthy inside minerals and pricey inside fiber, which can troth a colossal addition to any nutritious, nonetheless balanced diet. Bamboo offers a product of poles apart amino acids, including eight styles of amino acids that humans must get indulge in a cuisine source, since the body attains not manufacture these most amino acids within the body. Bamboo shoots contain high protein but less fat, moderate dietary fiber, having essential amino acids, selenium, potassium, a potent antioxidant and minerals for healthy heart.

Besides all the versatile uses of bamboo, people has been using shoots of this plant as one of his food items since prehistoric days when they were ignorant about vegetable growing. Young shoots of several species of bamboo are used as important vegetable in the daily meals in China, Japan, Taiwan and Thailand.

\section{Uses of bamboo as medicine}

Medicinal uses of bamboo have been known and practiced by Asian healers of old. Bamboo shoots are good for the stomach and can cure mild symptoms like indigestion and diarrhoea. Studies have indicated that consuming bamboo shoots can reduce cholesterol and thus, ensure a healthier life. Bamboo is also used in aromatherapy as it known to be a natural exfoliant. Antioxidants help to keep the balance of free radicals and ward off any excess amount that can cause a large variety of problems like heart disease and even cancer. It is also great for healthy skin. Women suffering from menstrual irregularities or disorders can find benefit through the intake of bamboo shoots that help to regulate the cycle. If you are consuming fresh shoots, take care to boil them thoroughly for about half an hour in salt water. This helps to remove the raw taste and also kill germs, bacteria, and toxins. Certain varieties of bamboo shoots are not good for pregnant women as they are said to have abortive properties. Potassium is an important mineral of our body and great for general health and robust muscle function. Fiber has many benefits some of which help to prevent diabetes and heart disease. Bambusa arundinacea is highly reputed ayurvedic medicinal plant. Various parts of this plant such as leaf, root, shoot and seed possess antiinflammatory, antiulcer, anti-diabetic, anti-oxidant, anthelmintic and astringent activity (Rathod Jaimik, 2011).

\section{Conclusion}

Research has revealed that bamboo shoots have various health benefits. So, it is necessary to promote bamboo cultivation through appropriate methods. As well as verify the impacts of the plants extract in human body as traditional medicine by using modern technology for further recommendation.

\section{Conflict of interest statement}

Authors declare that they have no conflict of interest. 


\section{References}

Bess, N. M., Wein, B., 1987. Bamboo in Japan. Kodansha International. 101p.

FAO, 2007. World bamboo resources: A thematic study prepared in the framework of the Global Forest Resources Assessment. Non-wood forest products18, Food and Agriculture Organization of the United Nations, Rome.

McClure, F. A., 1996. Bamboos. A Fresh Perspective. Harvard University Press, Cambridge, Mas, USA. $347 \mathrm{p}$.
Nijhuis, M., 2009. Bamboo Boom: Is This Material for You?". Scientific American Earth 3.0 special. Scientific American. Retrieved 11 August 2009.

Rathod Jaimik, D., Pathak Nimish, L., Patel Ritesh, G., Jivani, N.P., Bhatt Nayna, M., 2011. Phytopharmacological properties of Bambusa arundinacea as a potential medicinal tree: An overview. J. Appl. Pharmaceut. Sci. 1(10), 27-31.

Sharma, Y.M.L., 1987. Inventory and resources of bamboos. In: Recent Research on Bamboos (Eds.: Rao, A.N., Dhanarajan, G., Sastry, C.B.). CAF, China and IDRC, Canada. pp.14-17.

How to cite this article:

Singh, G., Richa, Sharma, M. L., 2017. Bamboo - A miracle plant. Int. J. Curr. Res. Biosci. Plant Biol. 4(1), 110-112. doi: http://dx.doi.org/10.20546/ijcrbp.2017.401.013 